\title{
Assessment of archaeol as a molecular proxy for methane production in cattle
}

\author{
C. A. McCartney, ${ }^{*} \dagger^{1,2}$ I. D. Bull, ${ }^{*}$ T. Yan, $\ddagger$ and R. J. Dewhurst $\dagger$ \\ ${ }^{*}$ Organic Geochemistry Unit, Bristol Biogeochemistry Research Centre, University of Bristol, School of Chemistry, Cantock's Close, \\ Bristol, BS8 1TS, United Kingdom \\ †Teagasc, Animal and Grassland Research and Innovation Centre, Grange, Dunsany, Co. Meath, Ireland \\ ¥Agri-Food and Biosciences Institute, Large Park, Hillsborough, Co. Down, BT26 6DR, United Kingdom
}

\begin{abstract}
The objective of this study was to assess archaeol, a membrane lipid present in methanogenic Archaea, in cattle feces as a molecular proxy for methanogenesis in the rumen. Feces from 16 heifers either in early lactation [71 d in milk (DIM)] or mid lactation (120 DIM), consuming a diet consisting of $30 / 70$ grass silage/ concentrates [dry matter (DM) basis], were analyzed for archaeol. To prepare the feces for analysis, total lipids were obtained by Bligh-Dyer extraction, polar head groups were removed by acid methanolysis, an alcohol fraction was obtained by column chromatography, and finally, the alcohol fraction was trimethylsilylated before analysis by gas chromatography-mass spectrometry. Archaeol was quantified by comparison to an internal standard. A highly significant positive relationship was found between fecal archaeol concentration $(\mathrm{mg} / \mathrm{kg}$ of DM) and methane output $(\mathrm{g} / \mathrm{kg}$ of DM intake). A highly significant effect of stage of lactation on this relationship was observed. The significant relationship was surprising, given the lack of agreement between methane and total methanogens in previous studies using molecular biology techniques. Variation in the relationship between fecal archaeol concentrations and methane output could be attributed to differences in the methane-producing capability per cell and the selective retention of methanogens in the rumen. The effect of stage of lactation may have been due to differences in DM intake, affecting rumen passage rates and, thus, methanogen populations and activities.
\end{abstract}

Key words: enteric methane, archaeol, rumen methanogen, calorimetric chamber

\section{INTRODUCTION}

Concerns over agricultural methane emissions have resulted in a focus on methane mitigation technologies,

Received August 8, 2012.

Accepted October 28, 2012.

${ }^{1}$ Corresponding author: Christine.McCartney@abdn.ac.uk

${ }^{2}$ Current address: Rowett Institute of Nutrition and Health, University of Aberdeen, Greenburn Road, Aberdeen, AB21 9SB, UK. which have been the subject of several recent reviews (Eckard et al., 2010; Martin et al., 2010; Buddle et al., 2011). Methane mitigation studies require reliable methane production measurements, with the 2 main options for measuring methane in cattle being opencircuit calorimetric chambers (Blaxter and Clapperton, $1965)$ and the sulfur hexafluoride $\left(\mathrm{SF}_{6}\right)$ technique (Johnson et al., 1994). These methods can both be problematic (Pinares-Patiño et al., 2011), so several alternative methods have emerged, including micrometeorological techniques (Harper et al., 2011; Tomkins et al., 2011), laser methane detectors (Chagunda and Yan, 2011), and portable static chambers (Goopy et al., 2011). Another alternative is the use of archaeol (2,3-diphytanyl-O-sn-glycerol), which is a membrane lipid ubiquitous in methanogens that can be quantified by GC-MS after extraction, separation from the total lipid extract (TLE) of feces, and trimethylsilylation of the isolated alcohol fraction. Gill et al. (2011) studied archaeol as a potential molecular proxy for methanogenesis in cattle fed either a grass- or concentrate-based diet, where methane production was assessed using the $\mathrm{SF}_{6}$ technique. Although a clear correlation between fecal archaeol concentration and methane production for treatment means was observed, relationships between individual measurements within dietary treatments were weak.

Further studies are now required to elucidate the relationships between the concentration of archaeol in feces, the size of the methanogen population in the rumen, and methane output (Gill et al., 2011). The unknown elements of this relationship include possible selective retention of Archaea in the rumen; differences in species composition of the methanogen community, which might differ in archaeol concentration per cell; differences in the postrumen digestibility of archaeol; and the production of archaeol by nonmethanogenic Archaea. Uncertainties also exist about the large experimental error associated with the $\mathrm{SF}_{6}$ technique.

To ascertain whether the weak relationship was due to variability associated with the $\mathrm{SF}_{6}$ technique, and to remove the influence of diet, this study used methane 
measurements from open-circuit respiration calorimeters, which are more precise, and from animals fed the same diet. We hypothesize that a relationship exists between enteric methane production expressed relative to DMI by ruminants and the concentration of archaeol in their feces.

\section{MATERIALS AND METHODS}

\section{Animal Study}

Fecal samples were obtained from a previous study described by Xue et al. (2011). Briefly, 8 Jersey $x$ Holstein-Friesian heifers and 8 Holstein-Friesian heifers were split into 2 groups according to calving date, BW, milk yield, and BCS, with 4 of each breed in each group. After calving, the animals were offered a standard diet of grass silage and concentrates (50/50 on a DM basis) for approximately $28 \mathrm{~d}$. Silage offered came from the same silo, and a standard concentrate supplement prepared in the same batch was used throughout the study. Feeds were prepared, bagged, and frozen for future use in the study before the final $10 \mathrm{~d}$ of the first period. Animals in the first group (4 per breed) were offered a diet containing 30/70 grass silage/concentrates (DM basis) during the first period (approximately lactation wk 5 to 10), whereas the other 8 animals received a diet containing 70/30 grass silage/concentrates. The diets were switched during the second period (approximately lactation wk 11 to 18). The chemical compositions of the grass silages used in early and mid lactation are shown in Table 1. Total collections of feces and methane measurements using calorimetric chambers were made at $71(\mathrm{SD}=7.67)$ and $120(\mathrm{SD}=8.56) \mathrm{DIM}$ for the 2 groups of 8 animals offered the $30 / 70$ grass silage/concentrates diet, and at $85(\mathrm{SD}=12.22)$ and $114(\mathrm{SD}=6.45) \mathrm{DIM}$ for the animals offered the $70 / 30$ grass silage/concentrates diet. Feces were collected over $6 \mathrm{~d}$ and then pooled within animals, thoroughly mixed, and representative samples taken. These samples were

Table 1. Chemical composition of the grass silage used in early lactation and mid lactation

\begin{tabular}{lcc}
\hline Composition & $\begin{array}{c}\text { Early } \\
\text { lactation }\end{array}$ & $\begin{array}{c}\text { Mid } \\
\text { lactation }\end{array}$ \\
\hline $\mathrm{DM}, \mathrm{kg} / \mathrm{kg}$ & 260 & 266 \\
$\mathrm{CP}, \mathrm{g} / \mathrm{kg}$ of DM & 177 & 177 \\
$\mathrm{Gross}$ energy, MJ/kg of DM & 20.0 & 19.6 \\
$\mathrm{NDF}, \mathrm{g} / \mathrm{kg}$ of DM & 460 & 487 \\
$\mathrm{ADF}, \mathrm{g} / \mathrm{kg}$ of DM & 263 & 285 \\
Ether extract, g/kg of DM & 19.5 & 10.7 \\
Lactic acid, g/kg of DM & 43.4 & 43.0 \\
Acetic acid, g/kg of DM & 3.45 & 3.53 \\
Butyric acid, g/kg of DM & 0.16 & 0.19 \\
$\mathrm{pH}$ & 3.77 & 3.79 \\
$\mathrm{NH} \mathrm{H}_{3} \mathrm{~N} /$ total N, kg/kg & 0.07 & 0.07 \\
\hline
\end{tabular}

dried at $85^{\circ} \mathrm{C}$ for $72 \mathrm{~h}$ and then milled $(0.8-\mathrm{mm}$ sieve size) for analysis.

For the present study, samples were selected from animals offered the $30 / 70$ grass silage/concentrate diet (DM basis). This treatment group was selected on the basis of providing the widest range of methane measurements for animals receiving the same diet. One set of measurements was taken from animals in early lactation (71 DIM) and the other set of measurements was taken from a different group of animals in mid lactation (120 DIM), which enabled a preliminary evaluation of effects of lactation stage to be made.

\section{Archaeol Analysis}

All solvents were of HPLC grade. Aqueous solutions were formulated using double-distilled water preextracted 3 times with dichloromethane (DCM).

Lipid Extraction. An internal standard 1,2-di-Ohexadecyl-rac-glycerol (43.4 $\mu \mathrm{g}$; Santa Cruz Biotechnology Inc., CA) was added to approximately $300 \mathrm{mg}$ of the dried, ground feces (in triplicate) before extraction. The TLE was extracted using a modified monophasic extraction procedure (Bligh and Dyer, 1959). The monophasic solvent comprised buffered water, methanol, and chloroform in a ratio of 4:10:5 (vol:vol:vol). The buffered water was a potassium dihydrogen phosphate solution $(0.05 \mathrm{M})$, which was then buffered at $\mathrm{pH}$ 7.2 using potassium hydroxide pellets, and extracted 3 times using $50 \mathrm{~mL}$ of DCM. Monophasic solvent (2 $\mathrm{mL}$ ) was added to the feces, ultrasonicated for $15 \mathrm{~min}$, centrifuged $(990 \times g$ for $5 \mathrm{~min})$, with the supernatant containing the TLE decanted and retained. The feces were extracted again in this way a further 3 times. The combined extracts were then treated with $2 \mathrm{~mL}$ of buffered water and $2 \mathrm{~mL}$ of chloroform, vortexed, centrifuged $(990 \times g$ for $5 \mathrm{~min})$ and the organic (bottom) layer decanted and retained. The remaining aqueous layer was further rinsed with $2 \mathrm{~mL}$ of chloroform $(2 \times)$ and the combined extracts evaporated under a gentle stream of $\mathrm{N}_{2}$.

Removal of Polar Head Groups. Efficient removal of sugar- and phosphate-head groups from archaeol is necessary to make it amenable to analysis by GCMS. Acid methanolysis was used, where $5 \mathrm{~mL}$ of $5 \%$ hydrochloric acid in methanol was added to the TLE and heated in a tightly sealed boiling tube for $3 \mathrm{~h}$ at $100^{\circ} \mathrm{C}$. The acidified fraction was then allowed to cool, before $2 \mathrm{~mL}$ of double-distilled water and $2 \mathrm{~mL}$ of chloroform were added to separate the organic and aqueous phases. The organic (bottom) phase was retained, with the aqueous phase washed a further 2 times with chloroform. The combined extracts were evaporated under a gentle stream of $\mathrm{N}_{2}$. 
Lipid Fractionation. The TLE was separated over an activated silica column ( 0.5 g silica gel, $60 \AA$ particle size, activated at $125^{\circ} \mathrm{C}$, cooled to room temperature, and then immediately transferred to a glass column). The column was conditioned with DCM (2 column volumes) and the lipid mixture was applied to the column in the same solvent. An apolar fraction was then eluted with DCM (3 column volumes), followed by the alcohol fraction with DCM:methanol (1:1, vol:vol; 3 column volumes). Solvent was evaporated under a gentle stream of $\mathrm{N}_{2}$.

GC-MS Analysis. The alcohol fraction was derivatized by adding $50 \mu \mathrm{L}$ of $N, O$-bis(trimethylsilyl)trifluoroacetamide containing 1\% trimethylchlorosilane (BSTFA $+1 \%$ TCMS ) and heating at $70^{\circ} \mathrm{C}$ for $1 \mathrm{~h}$. The BSTFA was then gently evaporated under a gentle stream of $\mathrm{N}_{2}$. The samples were dissolved in ethyl acetate before analysis by GC-MS (Focus GC and DSQ II MS; Thermo Scientific, Hemel Hempstead, UK) fitted with a silica column coated with a nonpolar stationary phase (ZB-1, $60 \mathrm{~m} \times 0.32 \mathrm{~mm} \times 0.1 \mu \mathrm{m}$; Phenomenex Ltd., Macclesfield, UK). The GC oven was programmed from $70^{\circ} \mathrm{C}$, rising to $130^{\circ} \mathrm{C}$ at $20^{\circ} \mathrm{C} / \mathrm{min}$, and then rising to $300^{\circ} \mathrm{C}$ at $2^{\circ} \mathrm{C} / \mathrm{min}$ and held at $300^{\circ} \mathrm{C}$ for $25 \mathrm{~min}$. Archaeol was identified on the basis of its characteristic mass spectrum (key diagnostic ions being $m / z 130,278,284$, and 426; Teixidor and Grimalt, 1992) and retention time.

Archaeol Quantification. A calibration curve was made by running $100 \mathrm{ng} / \mu \mathrm{L}$ of internal standard (1,2-di-O-hexadecyl-rac-glycerol; $\mathbf{M}_{\text {std }}$ ) along with 5, $25,50,150$ and $250 \mathrm{ng} / \mu \mathrm{L}$ of archaeol standard (1,2-di$O$-phytanyl-sn-glycerol; $\mathbf{M}_{\mathbf{x}}$ ) using GC-MS. The peak areas of the internal standard $\left(\mathbf{A}_{\text {std }}\right)$ and archaeol standard $\left(\mathbf{A}_{\mathbf{x}}\right)$ were determined. The ratio of the standard in $n g\left(M_{x} / M_{s t d}\right)$ was plotted against the ratio of the areas $\left(A_{x} / A_{\text {std }}\right)$, and the resulting regression equation for the slope was

$$
\mathrm{A}_{\mathrm{x}} / \mathrm{A}_{\text {std }}=1.32 \mathrm{M}_{\mathrm{x}} / \mathrm{M}_{\text {std }}-0.0708 .
$$

Because the graph is plotted with $\mathrm{A}_{\mathrm{x}} / \mathrm{A}_{\text {std }}$ on the $\mathrm{y}$ axis, the equation was rearranged to solve for $M_{x} / M_{\text {std }}$ on the x-axis:

$$
\mathrm{M}_{\mathrm{x}} / \mathrm{M}_{\mathrm{std}}=\left(\mathrm{A}_{\mathrm{x}} / \mathrm{A}_{\mathrm{std}}+0.0708\right) / 1.32 ;
$$

$43.4 \mu \mathrm{g}$ of internal standard was added to each sample; therefore,

$$
\mathrm{M}_{\mathrm{x}}=\left(\mathrm{A}_{\mathrm{x}} / \mathrm{A}_{\mathrm{std}}+0.0708\right) / 1.32 \times 43.4 .
$$

\section{Statistical Analysis}

Regression analysis was used to assess the relationship between fecal archaeol concentrations and methane production. Analysis of variance was also applied to archaeol, methane, and animal production data, using a treatment structure of period $\times$ breed. The statistical program used in this study was GenStat software (14th edition; VSN International Ltd., Hemel Hempstead, UK).

\section{RESULTS}

Xue et al. (2011) presented a full analysis of the effects of dietary treatment and breed on feed intake, milk output, and methane production. This analysis involved only one of the diets and presents additional analysis of the effects of stage of lactation. As shown in Table 2 , breed and the breed $\times$ stage of lactation interaction did not influence any of the animal performance, methane, or archaeol measurements. Furthermore, stage of lactation did not influence milk yield, $\mathrm{BW}$, or methane production $(\mathrm{g} / \mathrm{kg}$ of DMI); however, it did influence intake, with increased intakes of forage $(P$ $<0.001)$, concentrate $(P<0.05)$, and total DM $(P<$ $0.05)$ for cows in mid lactation. Stage of lactation also appeared to influence $(P<0.1)$ fecal archaeol $(\mathrm{mg} / \mathrm{kg}$ of $\mathrm{DM}$ and $\mathrm{mg} / \mathrm{kg}$ per day) and methane production (g/d).

Dry matter intake was higher for the mid-lactation group (17.3 vs. $14.9 \mathrm{~kg} / \mathrm{d}$; $\mathrm{SE}$ of the difference $=0.84$ $\mathrm{kg} / \mathrm{d} ; P=0.011)$. The mean CP content of the concentrates was 202 and $212 \mathrm{~kg} / \mathrm{kg}$ of DM for early and mid lactation, respectively. The chemical composition of the feeds was very similar to that in the main experiment (Xue et al., 2011) and did not differ between periods (Table 1).

The average coefficient of variation for the archaeol triplicates was $17.48 \%(\mathrm{SD}=1.82 \%)$. The mean archaeol concentration in feces was $9.17 \mathrm{mg} / \mathrm{kg}$ of DM $(\mathrm{SD}=4.97 \mathrm{mg} / \mathrm{kg}$ of $\mathrm{DM})$, and mean methane production was $20.87 \mathrm{~g} / \mathrm{kg}$ of DMI (SD $=3.23 \mathrm{~g} / \mathrm{kg}$ of DMI). Regression analysis showed a relationship between methane production, expressed on a DMI basis, and fecal archaeol concentration (Equation 1):

Methane production $(\mathrm{g} / \mathrm{kg}$ of DMI $)=16.72$

$$
\begin{gathered}
(\mathrm{SE}=1.47)^{* * *}+0.453(\mathrm{SE}=0.145) \\
\mathrm{mg} \text { of fecal archaeol } / \mathrm{kg} \text { of } \mathrm{DM}^{* *} ;
\end{gathered}
$$

$\mathrm{R}^{2}=0.37 ;$ residual $\mathrm{SD}=2.57 ; \mathrm{n}=16 ; P=0.007, \quad[1]$

where $^{* * *}=P<0.001$ and ${ }^{* *}=P<0.01$. Including stage of lactation in the regression analysis suggests a difference between lactation periods in this relationship: 
Table 2. Effect of stage of lactation (early lactation vs. mid lactation) on animal performance, methane production, and fecal archaeol concentration

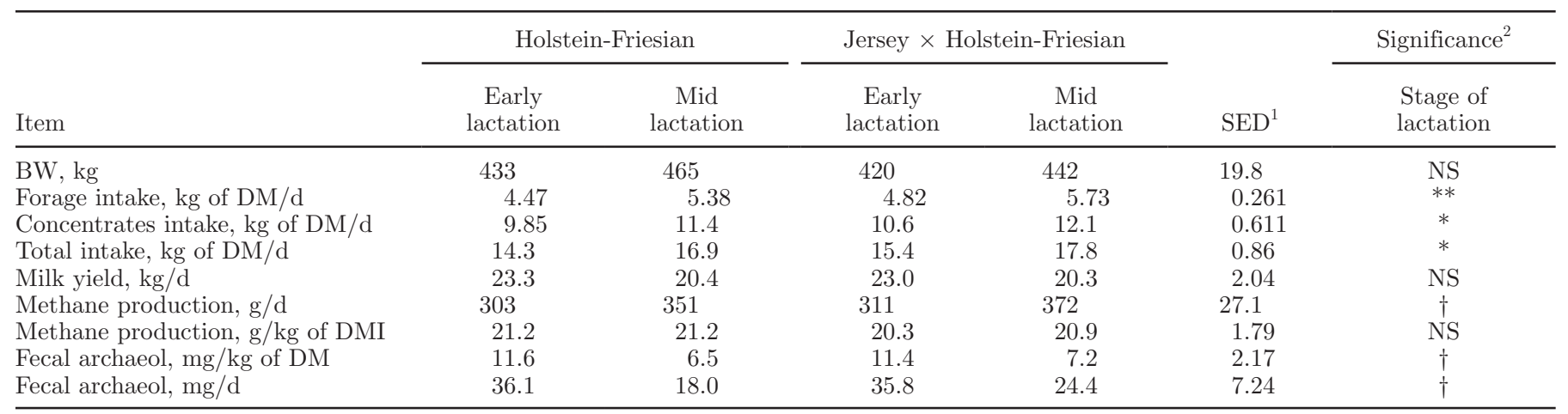

${ }^{1}$ Standard error of the difference.

${ }^{2}$ No significant effect was observed for breed or stage of lactation $\times$ breed.

$\dagger P<0.10 ;{ }^{*} P<0.05 ;{ }^{* *} P<0.01$.

Methane production $(\mathrm{g} / \mathrm{kg}$ of DMI $)=13.23$

$(\mathrm{SE}=1.80)^{* * *}+0.651(\mathrm{SE}=0.142) \mathrm{mg}$ of fecal

archaeol $/ \mathrm{kg}$ of $\mathrm{DM}^{* * *}+3.34(\mathrm{SE}=1.26)$ period*;

$\mathrm{R}^{2}=0.56 ;$ residual $\mathrm{SD}=2.15 ; \mathrm{n}=16 ; P=0.020, \quad[2]$

where ${ }^{*}=P<0.05$. Period was coded 1 for early lactation and 2 for mid lactation.

\section{DISCUSSION}

Some variation existed in the triplicate measurements for fecal archaeol (mg/kg; CV $=17.48 \%$; $\mathrm{SD}=1.82 \%)$. This could be explained by the heterogeneous nature of the feces and the small quantities used for each extraction $(300 \mathrm{mg})$. Another reason is the relatively low archaeol values due to the effects on methanogens on a high concentrate-based diet and subsequent detection issues in the GC-MS. Finally, the complicated method being used could cause variation; however, the internal standard added to the feces before extraction should account for any losses throughout the protocol. It is, therefore, important to take the average of the triplicates to obtain a meaningful overall estimate of archaeol for each sample.

Fecal archaeol concentrations $(\mathrm{mg} / \mathrm{kg}$ of $\mathrm{DM})$ in this study $[9.17 \mathrm{mg} / \mathrm{kg}$ of $\mathrm{DM}(\mathrm{SD}=4.97 \mathrm{mg} / \mathrm{kg}$ of $\mathrm{DM})]$ are for animals on a predominantly concentrate-based diet (30/70 grass silage/concentrates on a DM basis). This is in agreement with archaeol concentrations reported in a previous study by Gill et al. (2011), where animals on a concentrate-based diet (11/89 grass silage/ concentrates on a DM basis) had a slightly lower fecal archaeol concentration of $5.1 \mathrm{mg} / \mathrm{kg}$ of DM; however, this would be expected, as the level of concentrates was much higher than in the current study, and the associ- ated reductions in $\mathrm{pH}$ in the diet used by Gill et al. (2011) inhibit the growth of methanogens (Van Kessel and Russell, 1996).

The study by Gill et al. (2011) showed no significant linear relationship between fecal archaeol concentrations and methane yield ( $\mathrm{g} / \mathrm{kg}$ of DMI) within dietary treatment groups; however, a positive relationship was found in their study. The use of open-circuit respiration calorimeters to measure enteric methane may have improved the relationship, as these are known to be the gold standard for methane measurement, whereas the $\mathrm{SF}_{6}$ technique used by Gill et al. (2011) can be associated with large between-animal variation (PinaresPatiño et al., 2011). Methane production was expressed relative to DMI to put it on a similar basis to fecal archaeol, which was expressed relative to fecal DM.

\section{Factors Affecting the Relationship Between Fecal Archaeol and Methane}

Some unaccounted-for variation remains in the relationship between fecal archaeol and enteric methane production in addition to artifacts of the technique. Calorimetric chambers are highly accurate for measuring methane; therefore, the cause of this variation mostly lies with fecal archaeol measurements and its relationship with methane. Factors affecting this relationship include variations in the activity level and methaneproducing ability of each methanogen cell, selective retention of methanogens in the rumen, and the effect of intake and stage of lactation. These will now be described in more detail.

Variations in Methane Production Per Cell. A lack of a strong relationship between fecal archaeol and methane production may result from variation in the methane-producing activity of methanogens 
in the rumen. Earlier studies using molecular biology techniques have established no relationship between total methanogens and methane production, and have concluded that variation in the activity levels of rumen methanogens and population structure are the main contributors to methane production rather than total methanogen numbers (Machmüller et al., 2003; Mosoni et al., 2011; Zhou et al., 2011a). The significant positive relationship between our estimate of methanogen numbers, based on fecal archaeol and methane production suggests that the variation in activity levels is not so large and may be an artifact of the difficulties of the quantitative PCR technique. The limitations to using quantitative PCR include multiple copies of methanogen 16S rRNA within a gene (Masco et al., 2007; Hook et al., 2009), multiple genome copies within an individual methanogen cell (Hildenbrand et al., 2011), and the lack of methyl-coenzyme $\mathrm{M}$ reductase $\alpha$-subunit (mcrA) in the important rumen methanogen Methanosphaera stadtmanae (Zhou et al., 2011b). In addition, considerable amplification bias can be introduced by the use of universal archaeal primers (Tymensen and McAllister, 2012). It is, therefore, sensible to use multiple approaches to quantify methanogen cells (Huguet et al., 2010).

Differences in the growth rates of methanogens (Thauer et al., 2008) could also cause variations in the amount of methane produced per methanogen cell. Janssen and Kirs (2008) postulated that methanogens have dissimilar growth rates in multiple fractions of the rumen, which include rumen fluid, particulate material, rumen protozoa, and the rumen epithelium. For example, methanogens associated with the liquid phase may have higher growth rates than those associated with the solid phase in response to the faster turnover rates of this fraction. This is supported by older studies where faster fluid turnover rates were correlated with greater efficiency of microbial growth (Hartnell and Satter, 1979) and by the suggestion that particulate-associated methanogens were able to devote more energy to maintenance rather than protein synthesis (McAllister et al., 1994). Furthermore, the lack of particulate material in the liquid phase means that less potential exists for contact with syntrophic partners in a matrix for the interspecies hydrogen-transfer reactions that are important for methanogenesis (Conrad et al., 1985).

The Selective Retention of Methanogens. Another explanation for the variation in the relationship between fecal archaeol and methane may be selective retention of methanogens in the rumen. A positive intercept at the $y$-axis for methane production when archaeol concentrations are zero (Figure 1) infers that a population of methanogens is being retained in the rumen (perhaps protozoa-associated methanogens).

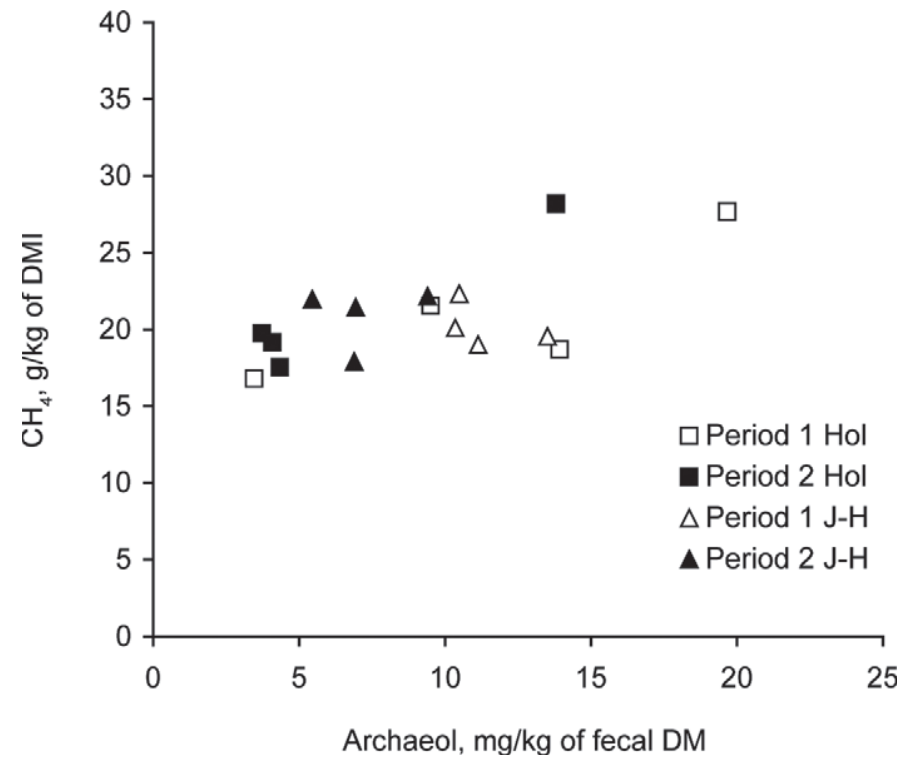

Figure 1. Archaeol concentration in feces $(\mathrm{mg} / \mathrm{kg}$ of $\mathrm{DM})$ from Holstein-Friesian $(\mathrm{Hol})$ and Jersey $\times$ Holstein-Friesian $(\mathrm{J}-\mathrm{H})$ cows either in early lactation (period 1) or mid lactation (period 2), in comparison with $\mathrm{CH}_{4}$ production $(\mathrm{g} / \mathrm{kg}$ of DMI) estimated by indirect open-circuit respiration calorimetry.

Once particles reach a suitable size and functional specific gravity, they gravitate from the rumen to the reticulum where they await expulsion at the reticuloomasal orifice (Hristov et al., 2003). There does not appear to be any further selective passage of material after the omasum through to the rectum (Ahvenjärvi et al., 2001). Archaeol is a fecal marker that relates back to methanogen activity in the rumen; therefore, the kinetics of methanogens in the rumen when particulate matter is being selectively retained before expulsion from the rumen is a potential source of variation. The contribution of hindgut fermentation to archaeol in ruminant feces is likely to be negligible, as a previous study by Gill et al. (2010) found no detectable levels of archaeol in the feces of animals that carry out hindgut fermentation (i.e., horses, zebras, elephants, and rhinoceroses).

The Stage of Lactation. The relationship between archaeol and methane production was influenced by stage of lactation. This could be explained by the observed significantly increased DMI in mid lactation. The limited intake in early lactation is thought to be affected by the reduced volume of the reticulorumen before parturition, which gradually increases over the first 2 mo of lactation (Allen, 1996) and, therefore, allows gradual greater DMI. It is well established that with increased DMI, methane emission $(\mathrm{g} / \mathrm{d})$ increases, but methane yield $(\mathrm{g} / \mathrm{kg}$ of DMI) decreases (Blaxter and Clapperton, 1965; Beauchemin et al., 2008). This is 
because increasing the DMI shortens the retention time of digesta, thereby decreasing the exposure of digesta to ruminal microbes (Luginbuhl et al., 1994). In fact, it is estimated that increasing DMI can decrease methane yield by up to $7 \%$ (Benchaar et al., 2001).

The increased level of intake affects solid (Evans, 1981a) and liquid (Evans, 1981b) turnover rate in the rumen. Colucci et al. (1990) found differential effects of increasing intake on the passage of forage, concentrate, and liquid fractions in the rumen. Depending on the distribution of methanogens in these fractions, this could affect the relationship between rumen methanogens and fecal archaeol. This relationship is further complicated by effects of passage rates on microbial energetics, as discussed above.

\section{CONCLUSIONS}

A positive significant relationship was found between fecal archaeol concentration and methane yield $(\mathrm{g} / \mathrm{kg}$ of DMI). This is surprising, given that no studies have found a relationship between estimates of methanogen numbers and methane production before, especially when using molecular biology methods. Variation existed in this relationship, which may be attributed to different levels of methane-producing activity in individual methanogen cells or selective retention of methanogens in the rumen. Stage of lactation affected this relationship also, which is most likely due to increased DMI in mid lactation, which results in a faster passage rate that can affect methanogens. The use of fecal archaeol as a molecular proxy for methane production is not straightforward. More work is needed to further analyze the cause(s) of variation in the relationship between fecal archaeol and methane yield.

\section{ACKNOWLEDGMENTS}

Funding from the Teagasc Walsh Fellowship Scheme is gratefully acknowledged.

\section{REFERENCES}

Ahvenjärvi, S., B. Skiba, and P. Huhtanen. 2001. Effects of heterogeneous digesta chemical composition on the accuracy of measurement of fiber flow in dairy cows. J. Anim. Sci. 79:1611-1620.

Allen, M. S. 1996. Physical constraints on voluntary intake of forages by ruminants. J. Anim. Sci. 74:3063-3075.

Beauchemin, K. A., M. Kreuzer, F. O'Mara, and T. A. McAllister. 2008. Nutritional management of enteric methane abatement: A review. Aust. J. Exp. Agric. 48:21-27.

Benchaar, C., C. Pomar, and J. Chiquette. 2001. Evaluation of dietary strategies to reduce methane production in ruminants: A modelling approach. Can. J. Anim. Sci. 81:563-574.

Blaxter, K. L., and J. L. Clapperton. 1965. Prediction of the amount of methane produced by ruminants. Br. J. Nutr. 19:511-522.
Bligh, E. G., and W. J. Dyer. 1959. A rapid method of total lipid extraction and purification. Can. J. Biochem. Physiol. 37:911-917.

Buddle, B. M., M. Denis, G. T. Attwood, E. Altermann, P. H. Janssen, R. S. Ronimus, C. S. Pinares-Patiño, S. Stefan, and D. N. Wedlock. 2011. Strategies to reduce methane emissions from farmed ruminants grazing on pasture. Vet. J. 188:11-17.

Chagunda, M. G. G., and T. Yan. 2011. Do methane measurements from a laser detector and an indirect open-circuit respiration calorimetric chamber agree sufficiently closely? Anim. Feed Sci. Technol. 165:8-14.

Colucci, P. E., G. K. Macleod, W. L. Grovum, I. McMillan, and D. J. Barney. 1990. Digesta kinetics in sheep and cattle fed diets with different forage to concentrate ratios at high and low intakes. J. Dairy Sci. 73:2143-2156.

Conrad, R., T. J. Phelps, and J. G. Zeikus. 1985. Gas metabolism evidence in support of the juxtaposition of hydrogen-producing and methanogenic bacteria in sewage sludge and lake sediments. Appl. Environ. Microbiol. 50:595-601.

Eckard, R. J., C. Grainger, and C. A. M. de Klein. 2010. Options for the abatement of methane and nitrous oxide from ruminant production: A review. Livest. Sci. 130:47-56.

Evans, E. 1981a. An evaluation of the relationships between dietary parameters and rumen solid turnover rate. Can. J. Anim. Sci 61:97-103.

Evans, E. 1981b. An evaluation of the relationships between dietary parameters and rumen liquid turnover rate. Can. J. Anim. Sci 61:91-96.

Gill, F. L., R. J. Dewhurst, J. A. J. Dungait, R. P. Evershed, L. Ives, C.-S. Li, R. D. Pancost, M. Sullivan, S. Bera, and I. D. Bull. 2010. Archaeol-A biomarker for foregut fermentation in modern and ancient herbivorous mammals? Org. Geochem. 41:467-472.

Gill, F. L., R. J. Dewhurst, R. P. Evershed, E. McGeough, P. O'Kiely, R. D. Pancost, and I. D. Bull. 2011. Analysis of archaeal ether lipids in bovine faeces. Anim. Feed Sci. Technol. 166-167:87-92.

Goopy, J. P., R. Woodgate, A. Donaldson, D. L. Robinson, and R. S. Hegarty. 2011. Validation of a short-term methane measurement using portable static chambers to estimate daily methane production in sheep. Anim. Feed Sci. Technol. 166:219-226.

Harper, L. A., O. T. Denmead, and T. K. Flesch. 2011. Micrometeorological techniques for measurement of enteric greenhouse gas emissions. Anim. Feed Sci. Technol. 166-167:227-239.

Hartnell, G. F., and L. D. Satter. 1979. Determination of rumen fill and ruminal turnover rates of ingesta at different stages of lactation in dairy cows. J. Anim. Sci. 48:381-392.

Hildenbrand, C., T. Stock, C. Lange, M. Rother, and J. Soppa. 2011 Genome copy numbers and gene conversion in methanogenic Archaea. J. Bacteriol. 193:734-743.

Hook, S. E., K. S. Northwood, A. D. G. Wright, and B. W. McBride. 2009. Long-term monensin supplementation does not significantly affect the quantity or diversity of methanogens in the rumen of the lactating dairy cow. Appl. Environ. Microbiol. 75:374-380.

Hristov, A. N., S. Ahvenjärvi, T. A. McAllister, and P. Huhtanen 2003. Composition and digestive tract retention time of ruminal particles with functional specific gravity greater or less than 1.02 . J. Anim. Sci. 81:2639-2648.

Huguet, C., H. Urakawa, W. Martens-Habbena, L. Truxal, and D. A. Stahl. 2010. Changes in intact membrane lipid content of archaeal cells as an indication of metabolic status. Org. Geochem. 41:930-934.

Janssen, P. H., and M. Kirs. 2008. Structure of the archaeal community of the rumen. Appl. Environ. Microbiol. 74:3619-3625.

Johnson, K., M. Huyler, H. Westberg, B. Lamb, and P. Zimmerman. 1994. Measurement of methane emissions from ruminant livestock using a $\mathrm{SF}_{6}$ tracer technique. Environ. Sci. Technol. 28:359-362.

Luginbuhl, J. M., K. R. Pond, and J. C. Burns. 1994. Whole-tract digesta kinetics and comparison of techniques for the estimation of fecal output in steers fed coastal bermudagrass hay at four levels of intake. J. Anim. Sci. 72:201-211.

Machmüller, A., C. R. Soliva, and M. Kreuzer. 2003. Effect of coconut oil and defaunation treatment on methanogenesis in sheep. Reprod. Nutr. Dev. 43:41-55. 
Martin, C., D. P. Morgavi, and M. Doreau. 2010. Methane mitigation in ruminants: From microbe to the farm scale. Animal 4:351-365.

Masco, L., T. Vanhoutte, R. Temmerman, J. Swings, and G. Huys. 2007. Evaluation of real-time PCR targeting the $16 \mathrm{~S}$ rRNA and rec $A$ genes for the enumeration of bifidobacteria in probiotic products. Int. J. Food Microbiol. 113:351-357.

McAllister, T. A., H. D. Bae, G. A. Jones, and K.-J. Cheng. 1994. Microbial attachment and feed digestion in the rumen. J. Anim. Sci. 72:3004-3018.

Mosoni, P., C. Martin, E. Forano, and D. P. Morgavi. 2011. Long-term defaunation increases the abundance of cellulolytic ruminococci and methanogens but does not affect the bacterial and methanogen diversity in the rumen of sheep. J. Anim. Sci. 89:783-791.

Pinares-Patiño, C. S., K. R. Lassey, R. J. Martin, G. Molano, M. Ferandez, S. MacLean, E. Sandoval, D. Luo, and H. Clark. 2011. Assessment of the sulphur hexafluoride $\left(\mathrm{SF}_{6}\right)$ tracer technique using respiration chambers for estimation of methane emissions from sheep. Anim. Feed Sci. Technol. 166-167:201-209.

Teixidor, P., and J. O. Grimalt. 1992. Gas chromatographic determination of isoprenoid alkylglycerol diethers in archaebacterial cultures and environmental samples. J. Chromatogr. A 607:253-259.

Thauer, R. K., A.-K. Kaster, H. Seedorf, W. Buckel, and R. Hedderich. 2008. Methanogenic Archaea: Ecologically relevant differences in energy conservation. Nat. Rev. Microbiol. 6:579-591.
Tomkins, N. W., S. M. McGinn, D. A. Turner, and E. Charmley. 2011. Comparison of open-circuit respiration chambers with a micrometeorological method for determining methane emissions from beef cattle. Anim. Feed Sci. Technol. 166:240-247.

Tymensen, L. D., and T. A. McAllister. 2012. Community structure analysis of methanogens associated with rumen protozoa reveals bias in universal archaeal primers. Appl. Environ. Microbiol. 78:4051-4056.

Van Kessel, J. A. S., and J. B. Russell. 1996. The effect of pH on ruminal methanogenesis. FEMS Microbiol. Ecol. 20:205-210.

Xue, B., T. Yan, C. F. Ferris, and C. S. Mayne. 2011. Milk production and energy efficiency of Holstein and Jersey-Holstein crossbred dairy cows offered diets containing grass silage. J. Dairy Sci. 94:1455-1464

Zhou, M., Y.-H. Chung, K. A. Beauchemin, L. Holtshausen, M. Oba, T. A. McAllister, and L. L. Guan. 2011a. Relationship between rumen methanogens and methane production in dairy cows fed diets supplemented with a feed enzyme additive. J. Appl. Microbiol. 111:1148-1158.

Zhou, M., T. A. McAllister, and L. L. Guan. 2011b. Molecular identification of rumen methanogens: Technologies, advances and prospects. Anim. Feed Sci. Technol. 166:76-86. 